\title{
Preparedness of Prospective Elementary School Teachers to Collaborate with Parents in Mathematics
}

\section{Radka Dofková}

\begin{abstract}
The goal of this article was to analyze basic aspects of preparedness of prospective elementary school Mathematics teachers to collaborate with parents. This article is based on a research project in which a total of 83 third and fourth year students of the programs of Teacher Training for Elementary Schools and Special Education and Teaching Children with Special Needs, and Teacher Training for Elementary Schools partook at the beginning of the 2017 summer semester. The research was based on seminar works "Preparedness to Teach Mathematics", which were analyzed using instruments typical for qualitative research.
\end{abstract}

Key words: teacher, Mathematics, student, parents, collaboration. 


\title{
Připravenost budoucích učitelů základních škol na spolupráci s rodiči v matematice
}

\begin{abstract}
Cílem tohoto článku bylo analyzovat základní aspekty připravenosti budoucích učitelů matematiky na základních školách spolupracovat s rodiči. Tento článek vychází z výzkumného projektu, na kterém spolupracovalo 83 studentů 3. a 4. ročníku studijních programů Učitelství pro 1. stupeň základních škol a speciální pedagogika a učitelství pro děti se speciálními potřebami a Učitelství pro 1. stupeň základních škol, a to na začátku letního semestru v roce 2017. Výzkum byl založený na seminárních pracích „Připravenost na výuku matematiky“, které byly analyzovány za použití nástrojů typických pro kvalitativní výzkum.
\end{abstract}

Klíčová slova: učitel, matematika, student, rodiče, spolupráce.

\section{Introduction}

Despite all educational reforms and various alternative approaches to education, the traditional model how a student's successfulness is perceived by their parents based on their good grades persists. Most parents are rather interested in the student's grades than their knowledge or their personality development, in spite of the fact that it should be the common focus of collaboration between the teacher and the parents to remove this anachronism, ideally in mutual collaboration if possible.

Developing a good relationship between school and family, however, should be the teacher's primary goal, since their character and quality largely depend on their ability to collaborate, initiate and develop. Therefore, the goal of this article is to identify strong and weak points in the preparedness of elementary school teachers to collaborate with parents in Mathematics.

\section{Introduction and Theoretical Background}

Teachers in elementary schools are the first to introduce children into school culture and the network of social relationships, new social roles, and are first to give them some bearings in order to become orientated in the world. It is obvious that socialization and personalization roles prevail in these teachers. Moreover, the socialization role is specifically emphasized during collaboration with parents. In the preparation of elementary school teachers we aspire to train such professionals who understand children, the sub- 
jects they teach, and also inherent general teacher education laws. They need to posses developed cognitive functions, the ability to creatively apply professional knowledge in new situations and contexts. However, inadequate preparation of teachers, namely in terms of collaboration with parents, is widely criticized.

\subsection{Historical Development}

Collaboration between school and family has long been the essence of multiple studies (Waggoner \& Griffith, 1998; Driessen, Smit \& Sleegers, 2005). In the previous conception of collaboration between school and family there was a significant difference between the goals within which various spheres of influence on children (students) were covered. The responsibility for education and upbringing was shared. Subsequently, Epstein (1995) formulated the typology of parent involvement as overlapping spheres of influence. The above mentioned typology includes six items: strengthening of parent skills, parent - school communication, voluntary parent work in school, parents tutoring children at home, parent participation in the decision making process in school, and collaboration within a wider community (Šed'ová, 2009).

Since the 1990s West Europe and the U.S.A. have stopped seeing the family - school relations as a utilitarian way to improve the child's results. Instead, these have started to be understood as part of parent rights in relation to the principles of civic society. The term parent involvement has been replaced by the term partnership. Partnership is defined as: "sharing power and responsibility between family and school, sharing common goals, responsible dialog including mutual listening to each other, the will to make compromises, and the commitment to act together" (Bastiani, 1993 in Šed'ová, 2009, p. 29).

A key moment in building an ideal partnership might be built through gradual implementation of five Bull steps: (1989, p. 114 in Gavora \& Majerčíková, 2012):

1. Informing parents of their children's grades.

2. Explaining and clarifying to parents what is going on in school.

3. Monitoring of what is going on in school by parents.

4. Parent participation as a form of support of the teacher and school.

5. Parent involvement in the decision making process regarding the organization and curricular matters of the school.

The sequence of these steps may be a practical instruction also for Mathematics didactics seminars how to design the program of parent involvement in the field of Mathematics. Through individual activities the students can prepare for building a functional relationship with parents, which will then take on the form of a partnership. 


\section{Strong and Weak Points of Preparedness for Collaboration with Parents in Mathematics}

As Smetáčková (2014) puts it, a Mathematics teacher is strongly determined in their teaching activity by their subjective teaching theory and their professional identity. In Mathematics didactics seminars within a teacher's preparation, however, these aspects are rarely emphasized strongly enough. It is obvious that it is mainly due to time reasons. However, the question is whether there should not be a space created for them in respect to the efficiency of their future work as teachers. Based on research ensuing from the international comparative study named Teacher Education and Development Study in Mathematics (TEDS-M) (Dofková, 2016, 72) states that students training to become Mathematics teachers do not feel prepared for this important part of their future career.

\subsection{Research Design}

At the beginning of the 2017 summer semester a total of 83 students of the third and fourth years of teacher training for elementary schools and special education (TTESSE) and teacher training for elementary schools (TTES) were given the seminar work of Selfreflection of preparedness for teaching Mathematics. There were 29 TTESSE students and 54 TTES students, and that was a $100 \%$ sample in the given school year. The students' goal was, using a prepared structure, to assess in writing their own preparedness to teach Mathematics, also in collaboration with parents ("Give your strong and weak points in terms of preparedness to collaborate with parents"). The students wrote down their assessment into a prepared template, which included the instruction that they were supposed to emphasize the main points in each area, and that the assessment must fit one letter size sheet of paper.

\subsection{Processing Results}

The first stage of data processing was to create codes of the research area being scrutinized. In compliance with the principles of anchored theory such a coding process was selected, during which "the text as a sequence is broken into units; these units are assigned names, and the researcher then works with these named (labeled) text fragments" (Švaříček, Šed'ová et al., 2007, 211).

The coding process was created in the QDA Miner program (Provalis Research) ${ }^{6}$. A total of 30 codes were created in two main areas: preparedness for collaboration with

6 Available at: https://provalisresearch.com/products/qualitative-data-analysis-software/ 
parents - strong points (RPA), and preparedness for collaboration with parents - weak points (RPN). The names of individual codes were created in such a way that there should not be any mistakes that generally happen during a coding process. The codes are unequivocal (not unnecessarily thin, nor thick), there are not too many of them, and unnecessarily long sections were not coded (same place).

A total of 13 codes were created in the RPA area, and 17 codes in the RPN area. Seven codes were identical in individual categories - preparedness in the area of argumentation with parents, every day communication, discussion about home preparation, assessment of personality qualifications for the given collaboration, dealing with conflicts with parents, informing parents of problems, general collaboration between parents and school, and communication at parent evenings.

The following codes were also identified in the RPA area:

- Conveying specific information of the children's grades to the parents (e.g. "I think I am able to defend my assessment - grades given to individual students");

- Advising parents (e.g. "I feel prepared to advise parents in terms of what and how they should practice with the students");

- Belief in consensus with parents (e.g. "I hope that I will not have a problem to reach agreement with parents. There is always a solution upon which both parties can agree').

- Down to earth approach to parents (e.g. "I would like to be open to parents but make it clear that I also need their support and want them to collaborate with us - the school, and help their children study at home");

- Experience collaborating with parents (e.g. "I am used to working with both children and parents so I think there won't be a problem here").

The remaining 10 codes in the RPN area concerned the following areas:

- Collaboration with arrogant parents (e.g. "I am a bit afraid to have children in class whose parents are trouble makers who will not allow me to explain them anything, will yell at me and complain");

- Concern regarding their handling of inclusion (e.g. "I am concerned with communication with parents of included children. I think they might have greater or different demands, and that they will try and advise me how to approach individual students");

- Concern regarding collaboration with parents using the so-called Hejný method (e.g. "In collaboration with parents I am the most insecure regarding home preparation. The Hejný method is often difficult for the parents to handle while trying to help their children do assignments");

- Dealing with noncollaboration from the parents' side (e.g. "I am the most insecure if the parents set their heads and won't budge");

- Parents prejudice against a starting teacher (e.g. "I am afraid that some parents won't trust me enough due to my age and the fact that I am still studying, or right after graduating from college"); 
- Concern regarding possible parent participation in lessons (e.g. "While parents attend lessons (e.g. during open doors days). The presence of other adults that may observe and assess me will probably be unpleasant for me and make me nervous");

- Concern regarding collaboration with parents who cannot accept criticism of their children - the parents of "know-alls" (e.g. "Unfortunately, there are also those types of parents who never admit mistakes on the part of their children or themselves, and won't accept advice');

- Concern regarding collaboration with the parents of weak or talented students (e.g. "In collaboration with the parents of a child who is not successful in Math");

- Concern regarding collaboration based on experience from elementary school, high school or college (e.g. "In my opinion I have to say that I don't think the faculty has prepared us adequately for confrontation with parents, unfortunately").

The following section lists the basic descriptive statistics of individual codes.

\subsection{Summary of Research Results}

Chart 1 makes it clear that the assessment of students in the RPA area, in respect to the frequency of the codes given, is identical. In both groups they are confident in regular communication with parents - 32 \% TTES and $23 \%$ TTESSE (e.g. "I have confidence in my ability to collaborate and positively communicate with parents who want to discuss work and the possibilities and options of improving their child's (and my student's) abilities, and assess this as my strong point"), and in personality qualifications - $28 \%$ of TTES and $19 \%$ of TTESSE (e.g. "I am confident in my nice and positive approach to people"). In third place $8 \%$ of the respondents in the TTES group and $11 \%$ of respondents in the TTESSE group state that they are confident in collaboration based on experience (e.g. "As I already have had some teaching practice I can say that even if it is sometimes not easy, if there is will on both the teacher's side and the parent's or student's side, then there is almost always a solution with which both parties would be satisfied"). On top of that, the same number of TTESSE respondents (11\%) mentioned belief in consensus with parents (e.g. "I believe that I will easily collaborate with parents who have a healthy interest in their child, and who are not trouble makers"). 


\section{Chart 1}

Answer frequencies in the RPA area

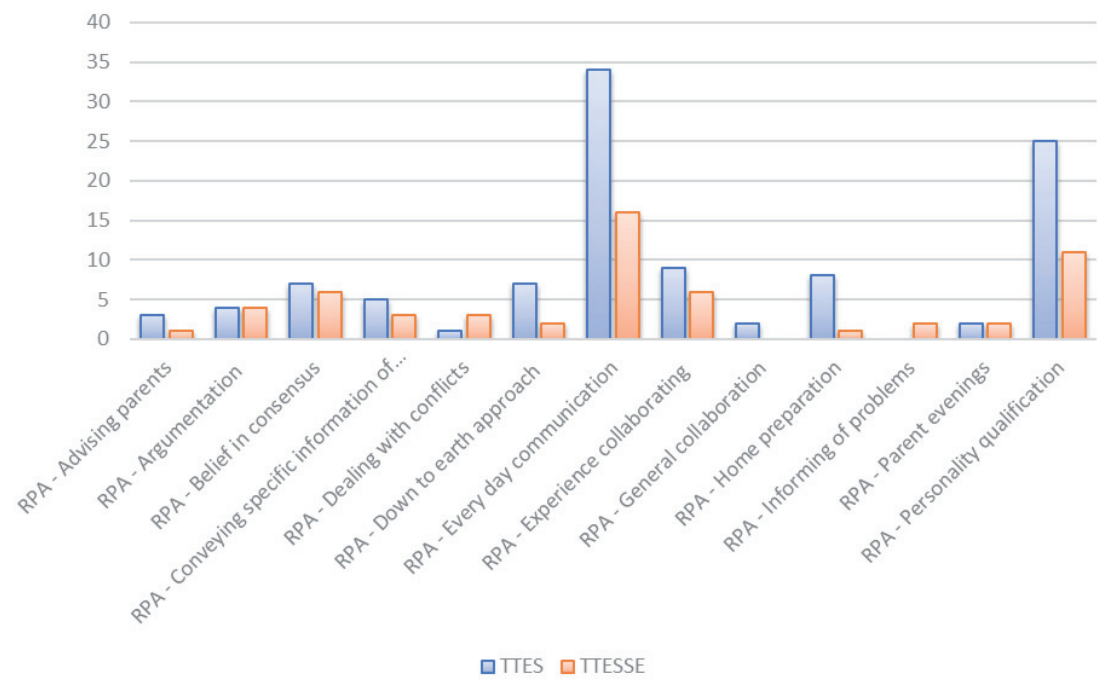

Chart 1 shows two more interesting facts - zero frequency of occurrence of the code meaning preparedness of students to convey problems with children to their parents in the TTES group (i.e. only TTES students feel prepared), and zero frequency of occurrence of the code meaning preparedness for collaboration between school and family, e.g. in extracurricular activities in the TTESSE group (only TTES students feel prepared in this respect). 


\section{Chart 2}

Answer frequencies in the RPN area

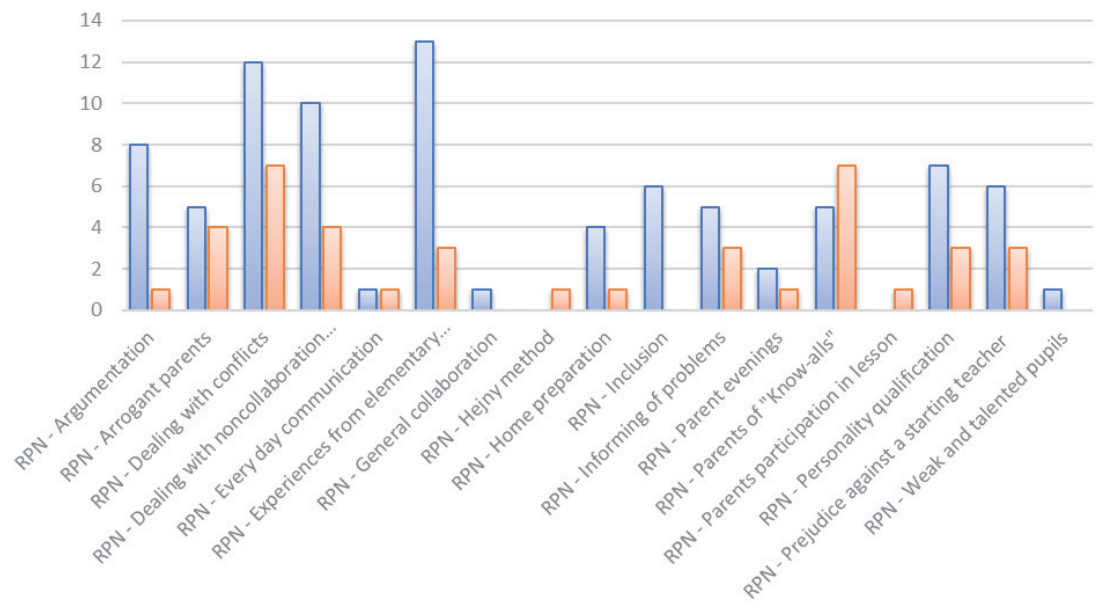

口TTES 口TTESSE

Chart 2 makes it clear that the assessment in the RPN area based on frequencies differs as early as in first place. A total of $15 \%$ of the respondents in the TTES group stated that they did not feel up to collaboration based on experience from elementary school, high school or college (e.g. "I am rather not confident. There is not such subject taught at the teacher education faculty that would focus on communication, collaboration and the right procedure while dealing with critical situations with parents"), whereas $18 \%$ of the TTESSE respondents stated shortcomings in preparedness to deal with conflicts with parents (e.g. "In personal direct conflict with a particular parent"), and the same number (18\%) concern of not being prepared for parents who refuse to collaborate (e.g. "I am least confident while dealing with non-collaboration").

Also here in Chart 2 we can identify some more interesting facts - zero frequency of occurrence in the TTES group in case of the codes of the Hejný method and parent presence in lessons. On the other hand, the inclusion code, the communication with parents of weak or talented students code, and the general collaboration between school and family codes were not even identified by the TTESSE group. 


\section{Conclusion}

Based on the above mentioned results it is obvious that the area of Mathematics teacher and family collaboration should have its place in Mathematics didactics seminars in the process of prospective teachers' preparation. In accordance with expectations, differences were found in assessment between the TTES and TTESSE groups. It is obvious that the TTES students feel more prepared for collaboration with parents given the fact that their children have special education needs. Adequate preparation could also help eliminate frequently mentioned concerns regarding the "starting teacher prejudice" - a self-confident teacher should not be afraid to defend their work processes and approach to children.

It is pleasant to find out that most students are not afraid to communicate with parents, have a positive approach to finding common solutions, and are self-confident in terms of personality qualifications. This can be considered as a good start for future work.

\section{Acknowledgements}

This paper was written with the support of the Grant Fund of the Dean of the Faculty of Education, Palacký University Olomouc.

\section{References}

Epstein, J. L. (1995). School/family/community partnerships, Phi Delta Kappan, 76(9), 71.

Dofková, R. (2016). Přesvědčení o připravenosti budoucích učitelů matematiky jako didaktická výzva primárního vzdělávání. Olomouc: VUP.

Driessen, G., Smit, F., \& Sleegers, P. (2005). Parental involvement and educational achievement. British educational research journal, 31(4), 509-532.

Gavora P., \& Majerčíková, J. (2012). Vnímaná zdatnost' (self-efficacy) učitel'a: oblast' vyučovania a oblast' spolupráce s rodičmi. Pedagogická orientace, 22(2), 205-221.

Smetáčková, I. (2014). Domácí příprava v matematice (na pozadí vztahu mezi rodinou a školou), Pedagogika, 64(2), 212-225.

Šed’ová, K. (2009). Tiché partnerství: vztahy mezi rodiči a učitelkami na prvním stupni základní školy. Studia paedagogica, 14(1), 27-52.

Švaříček, R., Šed’ová, K. (2007). Kvalitativní výzkum v pedagogických vědách. Praha: Portál.

Waggoner, K., \& Griffith, A. (1998). Parent Involvement in Education: Ideology and Experience. Journal for a Just and Caring Education, 4(1), 65-77. 


\section{Contact:}

PhDr. Radka Dofková, Ph.D.

Katedra matematiky PdF UP v Olomouci

Žižkovo nám. 5, 77140 Olomouc

E-mail: radka.dofkova@upol.cz

Phone: +420 585635709

PhDr. Radka Dofková, Ph.D. works as an assistant professor at the Department of Mathematics at the Faculty of Education, Palacký University Olomouc, Czech Republic, where she had trained before. She teaches didactics of Mathematics for elementary school teachers and subjects connected to modern trends in the field of teaching Mathematics. She has focused on Mathematics teachers' effectiveness, their perception of own successfulness, and preparedness to teach the subject. She regularly partakes in both domestic and international conferences focused on the topic in question. 